\title{
Efficiency of European Banks in the Aftermath of the Financial Crisis: A Panel Stochastic Frontier Approach
}

\author{
Cândida Ferreira ${ }^{1+}$ \\ ${ }^{1}$ ISEG, Universidade de Lisboa, UECE and REM, Portugal
}

\begin{abstract}
Using panel estimates and Stochastic Frontier Analysis this paper aims to contribute to the analysis of bank efficiency of the European banks in the aftermath of the international financial crisis and the sovereign crisis that seriously affected many EU countries. It also considers hypothetical scenarios of exit from the EU of some of the particularly relevant member-states, including the Brexit scenario. The results obtained very clearly demonstrate the existence of statistically significant technical inefficiencies in all considered scenarios. Nevertheless, the results reveal that the exclusion of the Italian banks and of the UK banks from our estimates would be more beneficial to the decrease of the banks' cost inefficiencies than the exclusion of the French and the German banks. Moreover, the worst scenario in terms of the decrease of the EU banks' cost inefficiencies would be the exclusion of the banks from the five EU countries that were deeply affected by the international financial and sovereign crises and were obliged to restructure their bank systems, that is, Cyprus, Greece, Ireland, Portugal and Spain.
\end{abstract}

Keywords: Bank efficiency, Stochastic Frontier Analysis, EU banking sector, Brexit JEL Classifications: C33, D24, F36, G21

Received 16 July 2019, Revised 14 April 2020, Accepted 11 September 2020

\section{Introduction}

In general, banks are expected to manage risks and help address potential adverse selection and moral hazard problems caused by imperfect information between borrowers and lenders. However, banks also have incentives to maximize high-value investment opportunities, and sometimes they fail to prevent risks and instead contribute to the financial distress and insolvencies that can lead to financial crises.

During the last decades, banking institutions have been exposed to new challenges, such

\footnotetext{
+Corresponding Author: Cândida Ferreira

Professor at ISEG, Universidade de Lisboa, R. Miguel Lupi, 20, 1249-078 - Lisboa, Portugal, Tel: +351-21-392-5800, Email: candidaf@iseg.ulisboa.pt
}

Acknowledgements: We would like to thank two anonymous referees and the participants at the 21 st Annual Conference of the International Network for Economic Research (INFER), Brussels, 5th-7th June 2019, for their most helpful comments, criticisms and suggestions. The usual disclaimer remains.

Financial support by FCT (Fundação para a Ciência e a Tecnologia), Portugal is gratefully acknowledged. This article is part of the Strategic Project (UID/ECO/00436/2019). 
as increased liberalization, deregulation, technological changes, and internationalization. These challenges were particularly evident in the European Union (EU) after the implementation of the Single Market Programme and the introduction of the single currency, both of which were intended to remove barriers, increase competition, and contribute to bank efficiency.

In recent years, EU banking institutions have experienced phenomena related to European integration and the consequences of the strong turbulence caused by the global financial crisis that started in the United States. Some EU countries faced not only financial but also public budget imbalances and needed to request international financial assistance to overcome their financial and sovereign crises.

Currently, the EU is overcoming these crises and is trying to implement a banking union, but it is also experiencing new challenges. In particular, it is experiencing challenges related to the UK's exit, which is particularly relevant to the EU's financial and banking systems.

This study builds upon studies that use stochastic frontier analysis (SFA) to analyze banking institutions' efficiency, particularly recent works that analyze the performance of European banks. In particular, Vozková and Kuc (2017) conclude that the average inefficiency of European cooperative banks has been increasing since 2008 and that smaller banks are significantly more efficient than larger ones are over the period 2006-2015. Kuc (2018) examines the same time period and confirms that smaller European cooperative banks are significantly more cost efficient than larger ones are. Focusing on the period 2000-2013, Oliveira (2017) finds that, in 2013, the median European bank's costs were $25-100 \%$ greater than the efficient level and that the inefficiency of financial intermediation has been increasing over time.

Other studies also use SFA techniques to analyze European banks in the aftermath of the recent financial crisis. For example, Belke et al. (2016) compare European regions with different levels of development and conclude that the regions whose banks have better intermediation quality grow faster in "normal" times and are more resilient in "bad" times.

However, to the best of our knowledge, few studies have tested banking efficiency across all EU countries for the period 2011-2017, and no previous studies use SFA panel estimates to answer this study's two main research questions. Specifically, these questions are:

1) How efficient are EU banks in the aftermath of the global financial crisis? To answer this question, we apply SFA to a panel that includes a relatively large sample of banks from all EU countries for the period 2011-2017.

2) How do EU banks perform in hypothetical scenarios in which some particularly relevant member-states exit the EU, including the Brexit scenario? To answer this question, we create six specific panels to represent some hypothetical scenarios. Specifically, in addition to the panel that includes banks from all current EU countries, we consider four panels that exclude banks from some financially relevant countries, that is, France, Germany, Italy, and the UK. The sixth panel excludes banks from the five EU countries that were 
primarily affected by the financial and sovereign crises and needed to request international financial assistance (i.e., Cyprus, Greece, Ireland, Portugal, and Spain).

The results reveal statistically significant technical inefficiencies in all panels. Moreover, in our sample of EU banks, the number of banks included in each of the subsamples and the loans provided in 2017 in these subsamples do not clearly correspond to the results regarding banks' cost inefficiencies. The results also show that, in general, excluding Italian or UK banks is more beneficial to the variation of banks' cost inefficiencies than excluding French or German banks is. Excluding Italian or UK banks decreases the distance to the minimum cost efficiency frontier, which is obtained through stochastic frontier estimates. The worst-case scenario is excluding the five EU countries that were deeply affected by the international financial and the sovereign crises and were required to restructure their bank systems (i.e., Cyprus, Greece, Ireland, Portugal, and Spain).

The remainder of this paper is organized as follows. Section 2 presents a brief literature review, and Section 3 presents the methodology and data. Section 4 reports the results, and Section 5 concludes.

\section{Brief Literature Review}

A very large strand of the literature analyzes bank efficiency and measures it using different methodological approaches. In this section, we do not aim to provide an extensive survey of the literature in this field; rather, we present a brief literature review. We highlight some relevant studies that discuss the concept of efficiency, particularly the definition of bank efficiency, and some empirical analyses addressing bank efficiency.

\section{A. Definition of bank efficiency}

The concept of efficiency, which includes bank efficiency, has been widely studied since Farrell's (1957) pioneering contribution. In general, studies of efficiency try to use available data on firms' inputs and outputs to define the efficiency frontier as the best combination of these inputs and outputs and then measure firms' efficiency according to their deviations from this efficiency frontier.

Bank efficiency is usually defined based on the assumption that each individual bank's performance can be described by a production function that links banking outputs to the necessary banking inputs. However, the literature has not reached a consensus definition of these banking outputs and inputs. Particularly, the specific role of bank deposits remains up for debate, as they may be considered either inputs or outputs in a bank's production function. 
Overall, the literature on bank efficiency uses two main approaches: the production approach and the intermediation approach.

First, the production approach treats banks as providers of services related to loans and deposits. Thus, like other producers, banks use labor and capital as inputs into a given production function. Details regarding this approach can be found, for example, in Berger and Humphrey (1991), Resti (1997), Rossi et al. (2005), and Goddard et al. (2014).

Second, the intermediation approach treats banks mainly as intermediaries between economic agents with excess financing capacity and economic agents that need support for their investments. Banks attract deposits and other funds and transform these funds into loans and investment securities using labor and other inputs, such as buildings, equipment, or technology. This approach is used by Sealey and Lindley (1977), Berger and Mester (1997), Altunbas et al. (2001), Bos and Kool (2006), and Barros et al. (2007), among many others.

The controversy regarding the appropriate set of banking inputs and outputs continues, as Doan et al. (2018), for example, point out. Doan et al. (2018) not only emphasize the lack of a general consensus in the literature regarding the definition of the relevant output vector but also note that models that ignore non-traditional outputs penalize banks that are heavily involved in such activities.

\section{B. Measuring bank efficiency}

Whether the production or the intermediation approach is used, bank efficiency is measured by estimating the efficiency frontier with the best combinations of the various inputs and outputs in the production process and then analyzing deviations from this frontier, which correspond to losses of efficiency.

Most empirical studies that measure bank efficiency adopt either non-parametric methods, such as data envelopment analysis (DEA), or parametric methods, such as SFA.

DEA was introduced by Charnes et al. (1978) and was further developed by Ali and Seiford (1993), Lovell (1993), Charnes et al. (1994), Cooper et al. (2006), and Chen et al. (2008), among others. DEA has been used widely in the last few decades to measure financial institutions' efficiencies by considering banks' abilities to produce outputs with minimal resources or inputs. This method typically considers the ratio of a bank's outputs to its inputs.

Presently, DEA is a well-tested non-parametric efficiency approach based on a linear programming methodology and is appropriate for measuring different decision-making units' efficiencies using multiple inputs and outputs in a production process. DEA has also become a method for evaluating performance and benchmarking against best practice (Cook et al., 2014).

DEA techniques are often used to assess and compare the efficiencies of banks in different countries or regions. Among many others, Ferreira (2020) presents and discusses some recent 
studies on the use of DEA to study bank efficiency. Recent examples of the use of DEA techniques to analyze European banks' efficiency include studies by Tuskan and Stojanovic (2016) and Kocisova (2017). Tuskan and Stojanovic (2016) study the efficiency of the banking industry for the period 2008-2012 using a sample of 28 European banking systems. Their results suggest that, in general, banking systems in post-transition countries are more cost efficient. Kocisova (2017) analyzes the revenue efficiency of EU countries' banking sectors in 2015 and mostly concludes that large banking sectors appear to be the most efficient.

Bank efficiency has also been analyzed extensively using parametric methods. In particular, SFA was first proposed by Aigner et al. (1977) and was later developed by Battese and Coelli (1988, 1995). SFA is based on a general economic optimization problem and can differentiate between the part of inefficiency that is mostly due to weaknesses in managerial performance and the part of inefficiency that represents statistical noise (as detailed in the next section).

Many empirical studies in the last decades use SFA to analyze bank efficiency in many countries and regions. Again, we do not aim to present an extensive and detailed survey of these studies. Instead, we focus on studies that use SFA to analyze the efficiency of European banks.

\section{Example uses of SFA to measure european banks' efficiency}

Resti (1997) uses both SFA and non-parametric techniques to evaluate the efficiency of a panel of 270 Italian banks and concludes that these banks' efficiency did not increase over the period 1988-1992.

Altunbas et al. (2001) use a large sample of European banks from 1989 to 1997 to show that banks of all sizes can obtain greater cost savings if they can reduce managerial and other kinds of inefficiencies.

Bikker (2003) empirically analyzes the evolution of the efficiencies of different categories of banks in 16 European countries during the period 1990-1997. This analysis reveals that inefficiencies were nearly 45\% lower in 1997 than in 1990. This result is explained by the financial and monetary integration in the EU that increased competitive pressure and forced European banks to operate more economically.

Casu et al. (2004) compare parametric and non-parametric estimates of productivity changes in European banking between 1994 and 2000 and suggest that any observed productivity growth is mainly brought about by improvements in the performances of best-practice banks.

Bos and Schmiedel (2007) use data on more than 5,000 large commercial banks from all major European banking markets over the period 1993-2004 to find evidence of a single European banking market characterized by cost and profit meta-frontiers.

Yildirim and Philippatos (2007) use SFA and the distribution-free approach to examine the 
cost and profit efficiencies of the banking sectors in twelve Central and Eastern European transition economies over the period 1993-2000. They find evidence of significant managerial inefficiencies.

Delis et al. (2009) estimate cost and profit stochastic frontiers based on a panel of Greek commercial banks over the period 1993-2005. They find that cost efficiency is lower than profit efficiency, although both measures improve over the sample period.

Weill (2009) uses SFA to analyze cross-country differences in banks' cost efficiencies throughout the EU from 1994 to 2005 and concludes that cost efficiency has improved for all EU countries and is converging across the EU.

Lozano-Vivas et al. (2011) use SFA to measure cost efficiency improvements and the effectiveness of merger processes and consolidations in Europe from 1998 to 2004.

Aiello and Bonanno (2013) evaluate the cost and profit efficiencies of the Italian banking sector over the period 2006-2011 and conclude that Italian banks perform well in general but that their performance is very heterogeneous.

Vozková and Kuc (2017) analyze recent trends in bank cost efficiency using SFA. They consider data from a sample of 649 European cooperative banks between 2006 and 2015 and show that average inefficiency of European cooperative banks is mostly increasing since 2008. Moreover, smaller cooperative banks are significantly more efficient than larger ones over the time period investigated.

Kuc (2018) applies SFA to a set of 183 cooperative banks from 12 European countries to investigate the relation between size and efficiency for European cooperative banks during the period 2006-2015. The study finds that smaller European cooperative banks are significantly more cost efficient than their larger peers are.

Oliveira (2017) analyzes the efficiency of European banks using SFA. Based on a set of 122 institutions, representing the largest banks from $15 \mathrm{EU}$ member-states for the period 2000-2013, he finds that, in 2013 the median European bank's costs were 25-100\% above the efficient level. Moreover, he concludes that the evidence on productivity growth is ambiguous but that the inefficiency of financial intermediation has been increasing over time, possibly driven by the least efficient banks.

Despite the validity of these results, it is also worth mentioning that some authors, such as Aiello and Bonanno (2015), document heterogeneity in the results of studies on banking efficiency. More precisely, they perform a meta-regression analysis examining 1,661 efficiency scores from 120 studies published over the period 2000-2014 and conclude not only that parametric methods yield lower levels of banking efficiency than non-parametric studies do but also that efficiency scores are determined by the quality of a study, the number of observations, and the variables used in the efficiency estimates. 


\section{Methodology and Data}

As we mention in the previous section, a bank's performance can be described by a production function linking the provided banking outputs to the necessary banking inputs. However, the literature has not reached a clear consensus regarding the definitions of banking's outputs and inputs.

The intermediation approach assumes that banks are mostly financial intermediaries that use deposits and other borrowed funds along with traditional factors of production, such as labor, to provide loans and other earning assets. The production approach assumes that banks are mostly producers of financial services, such as deposits, loans, and different kinds of financial transactions, and only use the traditional production factors, that is, labor and capital. However, in practice, the exact definition of banks' outputs and inputs is often restricted by data availability.

Usually, research on efficiency, including that on bank efficiency, estimates an efficiency frontier based on the best combinations of the various inputs and outputs in the production process. The deviation of an individual bank's performance from the "optimal" frontier provides a measure of that bank's efficiency loss.

One of the tested methods for empirically estimating banks' potential inefficiencies is SFA, a parametric method developed by Aigner et al. (1977), Battese and Coelli (1988, 1995), and Altunbas et al. (2001), among others.

SFA is based on an economic optimization problem. More precisely, this problem entails the maximization of profits or the minimization of costs given the assumption of a stochastic optimal frontier.

Following Altunbas et al. (2001), we represent the stochastic cost function by the expression

$$
T C=T C\left(Q_{i}, P_{j}\right)+\varepsilon
$$

where $T C$ is the total cost, $Q$ is a vector of $i$ outputs, $P$ is a vector of the prices of $j$ inputs, and $\varepsilon$ is the error term.

This error term of the cost function can be decomposed as $\varepsilon=u+v$, where $u$ and $v$ are independently distributed. The first part of this sum, $u$, is assumed to be a positive disturbance and represents the effects of inefficiency or weaknesses in managerial performance. This disturbance is assumed to follow a half-normal distribution that is truncated at zero, $\left[u \sim N^{+}\left(\mu, \sigma_{u}^{2}\right)\right]$, with non-zero mean $\mu$, as each unit's production must lie on or below its production frontier but above zero. The second part of the error term, $v$, represents a random disturbance and is assumed to follow a two-sided normal distribution with mean zero and variance $\sigma_{v}^{2}$. 
Because estimating the cost function only provides the value of the overall error term, $\varepsilon$, we still need to estimate the value of the inefficiency term, $u$. Following Jondrow et al. (1982) and Greene $(1990,2005)$, we decompose the total variance into $\sigma^{2}=\sigma_{u}^{2}+\sigma_{v}^{2}$, where $\sigma_{u}^{2}=\frac{\sigma^{2} \lambda^{2}}{1+\lambda^{2}}$ is the contribution of the inefficiency term, $\sigma_{v}^{2}=\frac{\lambda^{2}}{1+\lambda^{2}}$ is the contribution of noise, and $\lambda=\frac{\sigma_{u}}{\sigma_{v}}$ is the relative contribution of the inefficiency term. Moreover, the ratio of the variability of the inefficiency term, $u$, to the total variability is represented by $\gamma=\frac{\sigma_{u}^{2}}{\sigma_{u}^{2}+\sigma_{v}^{2}}$ or $\gamma=\frac{\lambda^{2}}{1+\lambda^{2}}$, where $0 \leq \gamma \leq 1$. Thus, if $\gamma$ is close to zero, the deviations of the costs are mostly due to statistical noise, whereas if $\gamma$ is close to one, these deviations are mostly related to the presence of technical inefficiencies.

This ability to differentiate statistical noise $(v)$ from inefficiency deviations $(u)$ is a recognized advantage of SFA. Another important advantage of this method is that it is not sensitive to outliers. Thus, if our estimations include a variable that is not clearly relevant, this variable's weighting in the efficiency measurements is very low, and its impact is negligible.

Despite the lack of consensus regarding the precise definitions of banking outputs and inputs, it is generally accepted that banks attract deposits and other funds and transform those funds into loans and other assets or securities using labor and other types of inputs, such as buildings, equipment, and technology.

The data used in this study are taken from the BankFocus database from Moody's Analytics, which combines the well-known data content of Bureau van Dijk and Moody's Investors Services with the expertise of Moody's Analytics. Although this database provides comprehensive information, however, data are still missing for some years and indicators for the universe of European banks, restricting our choices in terms of the banks included in our sample and the definitions of banks' outputs and inputs. Because we want to compare the performances of some panels of banks from different EU countries, we do not consider different categories of banks (e.g., public or private, big or small, universal or specialized, or national or regional banks), nor do we assume different technologies for distinct categories of banks. The importance of the different technology regimes in banking is well addressed by, for example, Koetter and Poghosyan (2009).

We follow the intermediation approach, and we use the natural logarithms of the selected variables to estimate a function with total cost (defined as the sum of interest and non-interest expenses) as the dependent variable. We consider two models. One includes three outputs, that is, total loans, other earning assets, and non-earning assets (Model 1), and the other only includes total loans and other earning assets as outputs (Model 2).

In both models, we consider two inputs: the price of borrowed funds (defined as the ratio 
of interest expenses to deposits and short-term funding) and the price of capital and labor (proxied by the ratio of non-interest expenses to total assets).

These outputs and inputs reflect not only our choice of the intermediation approach but also restrictions in terms of the available data, particularly related to the use of capital and labor. Other studies adopt similar solutions to this problem (Belke et al., 2016; Lozano-Vivas \& Pasiouras, 2010; Weill, 2009).

Our models also include some other control variables that represent banks' performance and influence banks' costs: the ratio of bank equity to total assets, the ratio of off-balance sheet items to total assets, the ratio of non-performing loans to gross loans, and the ratio of profits before tax to average assets. The ratio of equity to total assets is included as a proxy for leverage and represents the differing risk preferences across banking institutions (e.g., Apergis, 2015; Apergis \& Alevizopoulou, 2011; Bikker et al., 2012). The ratios of off-balance sheet items to total assets and of non-performing loans to gross loans are included to take into account non-traditional bank activities and the risks inherent in banking operations (e.g., Chiu et al., 2011; Guarda et al., 2013; Hughes \& Moon, 2018; Mamatzakis, 2015). Several recent studies opt to include non-performing loans as undesirable outputs when estimating their efficiency frontiers (e.g., Belke et al., 2016; Boussemart et al., 2017; Colesnic et al., 2018; Maggi, 2016; Matthews, 2010).

Our estimations also include the ratio of profits before tax to average assets as a control variable. We aim to analyze the influence of banks' profitability (e.g., Albertazzi \& Gambacorta, 2009; Athanasoglou et al. 2008; Kok et al., 2015; Martinho et al., 2017).

Because we aim to both measure the EU banking sector's efficiency and analyze the effects of some relevant countries' eventual exits, we consider six panels in our estimates 1 ). First, we include the full sample of banks from all current EU member-states. Then, we consider four panels, each of which excludes the banks of one of four relevant EU countries, that is, France, Germany, Italy, or the UK. Finally, we consider a panel that excludes the banks of five countries that were deeply affected by the global financial and sovereign crisis and had to overcome very challenging problems, some of which were related to their banking institutions' performance: Cyprus, Greece, Ireland, Portugal, and Spain.

Table 1 presents the six balanced panels used in our estimates. These panels are mainly restricted by the available data in the BankFocus database from Moody's Analytics over the period from 2011 to 2017. The data illustrate the relevance of the countries that are excluded from the full sample in each of the subsamples in terms of both the percentage of banks and the percentage of the loans provided in 2017. For example, UK banks represent $8 \%$ of the

1) The advantages and disadvantages of using panel data are already clearly discussed in the literature (e.g., Wooldridge, 2010). Here, it is worth underscoring that the use of panel data provides not only more informativeness, more degrees of freedom, and more efficient estimates but also less multicollinearity among the considered variables. 
banks in our sample but more than $22 \%$ of the loans provided by our full sample of EU banks in 2017. Conversely, Italian banks represent almost $22 \%$ of the banks included in the full sample but only $9 \%$ of the loans provided by the full sample of EU banks in 2017 (the number of banks from each EU member-state and their representativeness are presented in Annex I).

Table 1. Composition and Relevance of the Six Panels Considered in the Estimations

\begin{tabular}{clccc}
\hline \multicolumn{1}{c}{ Composition } & $\begin{array}{c}\text { Number of } \\
\text { banks }\end{array}$ & $\begin{array}{c}\text { \% of the } \\
\text { total banks }\end{array}$ & $\begin{array}{c}\text { \% of the provided } \\
\text { loans in } 2017\end{array}$ \\
\hline Panel 1 & Banks from all EU countries & 485 & 100 & 100 \\
Panel 2 & Without French banks & 441 & 91.13 & 77.31 \\
Panel 3 & Without German banks & 382 & 78.76 & 89.83 \\
Panel 4 & Without Italian banks & 380 & 78.35 & 91.04 \\
Panel 5 & Without UK banks & 447 & 91.96 & 77.84 \\
Panel 6 & Without banks from 5 EU countries ${ }^{(*)}$ & 453 & 93.4 & 88.45 \\
\hline
\end{tabular}

Note. ${ }^{(*)}$ The excluded EU member-states in Panel 6 are Cyprus, Greece, Ireland, Portugal, and Spain.

\section{Results}

Table 2 summarizes the results of our panel stochastic frontier estimates 2 ) for the two models and the six panels (see Annex II for detailed information about the SFA results). The results of the Wald and the log-likelihood tests shown in Table 2 allow us to conclude that the specified cost functions fit the data well in both models. In all cases, we can reject the null hypothesis that there is no inefficiency.

The robustness of the results obtained using Model 1 (including loans, other earning assets, and non-earning assets as outputs) are fully confirmed by those using Model 2 (excluding non-earning assets from the outputs).

Not surprisingly, in all cases, the elasticity of the cost relative to each of the considered outputs is positive, meaning that an increase in production contributes to growth in costs. Moreover, as expected, total costs are higher if the costs of the considered production inputs (that is, the prices of borrowed funds and of capital and labor) are higher.

2) We use STATA statistical software for our estimates, and the hypotheses are well described by, for example, Federico et al. (2013). More precisely, we use the specific STATA command for stochastic frontier estimates (xtfrontier), which, according to STATA's explanation, "fits stochastic production or cost frontier models for panel data where the disturbance term is a mixture of an inefficiency term and the idiosyncratic error." However, we are fully aware that we should interpret the results with caution owing to some of the drawbacks of this methodology. Namely, these drawbacks include those related to the possible existence of nonlinearities, which is clearly discussed by Greene (2005), for example, and the importance of the different technology regimes, which is well addressed, for example, by Koetter and Poghosyan (2009). 
Table 2. Summary of the Results of Panel Stochastic Frontier Estimates ${ }^{(*)}$

\begin{tabular}{|c|c|c|c|c|c|c|c|c|c|c|c|c|}
\hline \multirow{2}{*}{ PANELS $^{(* *)}$} & \multicolumn{2}{|c|}{ PANEL 1} & \multicolumn{2}{|c|}{ PANEL 2} & \multicolumn{2}{|c|}{ PANEL 3} & \multicolumn{2}{|c|}{ PANEL 4} & \multicolumn{2}{|c|}{ PANEL 5} & \multicolumn{2}{|c|}{ PANEL 6} \\
\hline & $\begin{array}{c}\text { Model } \\
1\end{array}$ & $\begin{array}{l}\text { Model } \\
2\end{array}$ & $\begin{array}{c}\text { Model } \\
1\end{array}$ & $\begin{array}{c}\text { Model } \\
2\end{array}$ & $\begin{array}{c}\text { Model } \\
1\end{array}$ & $\begin{array}{c}\text { Model } \\
2\end{array}$ & $\begin{array}{c}\text { Model } \\
1\end{array}$ & $\begin{array}{c}\text { Model } \\
2\end{array}$ & $\begin{array}{c}\text { Model } \\
1\end{array}$ & $\begin{array}{c}\text { Model } \\
2\end{array}$ & $\begin{array}{c}\text { Model } \\
1\end{array}$ & $\begin{array}{c}\text { Model } \\
2\end{array}$ \\
\hline Loans & $+* * *$ & $+* * *$ & $+* * *$ & $+* * *$ & $+* * *$ & $+* * *$ & $+* * *$ & $+* * *$ & $+* * *$ & $+* * *$ & $+* * *$ & $+* * *$ \\
\hline Other Earning Assets & $+* * *$ & $+* * *$ & $+* * *$ & $+* * *$ & $+* * *$ & $+* * *$ & $+* * *$ & $+* * *$ & $+* * *$ & $+* * *$ & $+* * *$ & $+* * *$ \\
\hline Non-Earning Assets & $+* * *$ & & $+* * *$ & & $+* * *$ & & $+* * *$ & & $+* * *$ & & $+* * *$ & \\
\hline Price of borrowed funds & $+* * *$ & $+* * *$ & $+* * *$ & $+* * *$ & $+* * *$ & $+* * *$ & $+* * *$ & $+* * *$ & $+* * *$ & $+* * *$ & $+* * *$ & $+* * *$ \\
\hline Price of capital and labour & $+* * *$ & $+* * *$ & $+* * *$ & $+* * *$ & $+* * *$ & $+* * *$ & $+* * *$ & $+* * *$ & $+* * *$ & $+* * *$ & $+* * *$ & $+* * *$ \\
\hline Equity/Total Assets & $-* * *$ & $-* * *$ & $-* * *$ & $-* * *$ & $-* * *$ & $-* * *$ & $-* * *$ & $-* * *$ & $-* * *$ & $-* * *$ & $-* * *$ & $-* * *$ \\
\hline Off-Balance Sheet Items/ Total Assets & $-* * *$ & $-* * *$ & $-* * *$ & $-* * *$ & $-* *$ & $-* * *$ & $-* *$ & $-* * *$ & $-* * *$ & $-* * *$ & $-* * *$ & $-* * *$ \\
\hline Non-Perf. Loans / Gross Loans & $+* * *$ & $+* * *$ & $+* * *$ & $+* * *$ & + & $+* *$ & $+* * *$ & $+* * *$ & $+* * *$ & $+* * *$ & $+* * *$ & $+* * *$ \\
\hline Profit before tax/average assets & $+* * *$ & $+* * *$ & $+* * *$ & $+* * *$ & $+* * *$ & $+* * *$ & $+* * *$ & $+* * *$ & $+* * *$ & $+* * *$ & $+* * *$ & $+* * *$ \\
\hline Wald chi 2 & 22298.7 & 11051.2 & 19954.3 & 11079.6 & 21165.2 & 10338.5 & 19224.3 & 11995.7 & 22382.0 & 14604.7 & 18278.0 & 9305.8 \\
\hline Prob $>$ chi 2 & 0.0000 & 0.0000 & 0.0000 & 0.0000 & 0.0000 & 0.0000 & 0.0000 & 0.0000 & 0.0000 & 0.0000 & 0.0000 & 0.0000 \\
\hline Log likelihood & 855.96 & 565.70 & 752.93 & 489.95 & 792.37 & 507.45 & 603.03 & 405.00 & 828.40 & 601.70 & 784.22 & 520.51 \\
\hline $\mathrm{N}$ & 3395 & 3395 & 3087 & 3087 & 2674 & 2674 & 2660 & 2660 & 3129 & 3129 & 3171 & 3171 \\
\hline
\end{tabular}

With regard to the control variables, the results in Table 2 indicate that the elasticity of the total cost relative to the ratio of non-performing loans to gross loans is always positive, meaning that performing and non-performing loans have similar effects on total costs, although the statistical significances of these effects differ (as shown in Table 2 and more clearly documented in Annex II). In addition, the growth of the ratio of profits before tax to average assets always has a statistically significant effect and is in line with the growth in total costs.

Conversely, the elasticity of total costs relative to the ratios of equity to total assets and of off-balance sheet items to total assets is always negative and statistically significant. Thus, total costs do not increase with the growth of banks' equity, nor does it increase with the growth of banks' activities that are not included in their balance sheets.

Table 3 presents the values of the mean of the first part of the cost function's error term, which captures the effects of inefficiency and is represented by $\mu$. The results reveal the existence of technical inefficiencies that are almost always statistically significant. These inefficiencies are more evident in Model 2, which only includes two outputs: loans and other earning assets. 
Table 3. Values of the Mean of First Part of the Cost Function's Error Term $(\mu)$

\begin{tabular}{|c|c|c|c|c|c|c|}
\hline \multirow{2}{*}{ Panel $^{(*)}$} & \multicolumn{3}{|c|}{ MODEL 1} & \multicolumn{3}{|c|}{ MODEL 2} \\
\hline & Coefficient & Z & $\mathrm{P}>|\mathrm{z}|$ & Coefficient & z & $\mathrm{P}>|\mathrm{z}|$ \\
\hline Panel 1 & 1.301111 & 2.42 & 0.015 & .734889 & 9.08 & 0.000 \\
\hline Panel 2 & 1.339288 & 1.56 & 0.119 & .7984115 & 10.71 & 0.000 \\
\hline Panel 3 & 1.2525 & 1.69 & 0.091 & .7738093 & 10.49 & 0.000 \\
\hline Panel 4 & 1.675875 & 0.40 & 0.691 & 1.981322 & 0.39 & 0.697 \\
\hline Panel 5 & 1.839847 & 0.30 & 0.765 & 2.006634 & 0.31 & 0.756 \\
\hline Panel 6 & 1.273452 & 3.23 & 0.001 & .7554726 & 9.52 & 0.000 \\
\hline
\end{tabular}

Notes. ${ }^{(*)}$ Panel 1: Banks from all EU countries; Panel 2: Excluding France; Panel 3: Excluding Germany; Panel 4: Excluding Italy; Panel 5: Excluding the UK; Panel 6: Excluding five EU countries (i.e., Cyprus, Greece, Ireland, Portugal, and Spain).

The results in Table 4 confirm the existence of inefficiencies, as the values of the gammas $\left(\gamma=\frac{\sigma_{u}^{2}}{\sigma_{u}^{2}+\sigma_{v}^{2}}\right)$, which represent the contribution of the inefficiency term $(u)$ to the total error term, are all very high (between 0.8 and 0.9 ) and statistically significant.

The results clearly demonstrate that the inefficiencies are even higher in Model 2, revealing that the consideration of three outputs (i.e., loans, other earning assets, and non-earning assets) in Model 1 reduces the relevance of the bank cost inefficiency term in the total error term.

Furthermore, a careful analysis of the gamma $(\gamma)$ values in Table 4 shows that the inefficiency error terms are lower in Panel 4 and higher in Panel 6 in both models. These results indicate that the exclusion of Italian banks (our Panel 4) improves banks' cost efficiency and that the worst-case scenario for banks' efficiency is represented by Panel 6, that is, the exclusion of the banks from five EU countries that were deeply affected by the global financial and sovereign crises and needed to restructure their banking systems (i.e., Cyprus, Greece, Ireland, Portugal, and Spain).

Table 4. Summary of the Values of the Contribution of the Inefficient Error Term to Total Variance ( $\gamma)$

\begin{tabular}{cccccc}
\hline \multirow{2}{*}{ Panel $^{*}$} & \multicolumn{3}{c}{ MODEL 1 } & & \multicolumn{2}{c}{ MODEL 2 } \\
\cline { 2 - 3 } \cline { 5 - 6 } & Coefficient & Standard Error & & Coefficient & Standard Error \\
\hline Panel 1 & .8149317 & .0129716 & & .8875373 & .0117008 \\
Panel 2 & .803966 & .0143326 & & .8790965 & .0130558 \\
Panel 3 & .8051674 & .0155383 & & .8853834 & .0137433 \\
Panel 4 & .7999936 & .0148083 & & .8351319 & .0145627 \\
Panel 5 & .8105175 & .0130569 & & .8454453 & .012305 \\
Panel 6 & .8225118 & .0133963 & & .8980313 & .0113594 \\
\hline
\end{tabular}

Notes. ${ }^{(*)}$ Panel 1: Banks from all EU countries; Panel 2: Excluding France; Panel 3: Excluding Germany; Panel 4: Excluding Italy; Panel 5: Excluding the UK; Panel 6: Excluding five EU countries (i.e., Cyprus, Greece, Ireland, Portugal, and Spain). 
Comparing the variance of the error term associated with inefficiency $\left(\sigma_{u}\right)$ with that of the random disturbances $\left(\sigma_{v}\right)$, as shown in Table 5, reinforces the previous results. In all cases, the variance of the inefficiency error term is much greater than that of the noise.

Table 5. Summary of the Estimated Variances of the Inefficiency Error Term $\left(\sigma_{u}\right)$ and the Noise $\left(\sigma_{v}\right)$

\begin{tabular}{|c|c|c|c|c|c|c|c|c|}
\hline \multirow{3}{*}{$\operatorname{Panel}^{(*)}$} & \multicolumn{4}{|c|}{ MODEL 1} & \multicolumn{4}{|c|}{ MODEL 2} \\
\hline & \multicolumn{2}{|c|}{ sigma_u2 } & \multicolumn{2}{|c|}{ sigma_v2 } & \multicolumn{2}{|c|}{ sigma_u2 } & \multicolumn{2}{|c|}{ sigma_v2 } \\
\hline & Coef. & Stand. error & Coef. & Stand. Error & Coef. & Stand. error & Coef. & Stand. error \\
\hline Panel 1 & .0949857 & .0074096 & .0215709 & .0005829 & .1928718 & .0211833 & .0244394 & .0007063 \\
\hline Panel 2 & .0908196 & .007486 & .0221449 & .0006284 & .1808165 & .0205855 & .024868 & .0007393 \\
\hline Panel 3 & .0823197 & .0073811 & .0199195 & .000609 & .1793802 & .022376 & .0232215 & .0007507 \\
\hline Panel 4 & .0919917 & .0077609 & .0229988 & .0006956 & .1308513 & .0124452 & .0258321 & .0008036 \\
\hline Panel 5 & .0903276 & .0070008 & .0211167 & .0005887 & .1290426 & .0109571 & .0235901 & .0006718 \\
\hline Panel 6 & .1002227 & .0083183 & .0216269 & .0006084 & .2134477 & .0246559 & .0242363 & .0007272 \\
\hline
\end{tabular}

According to Table 5, the variances of the inefficiency error term are not greater than 0.1 in Model 1, whereas they range from 0.13 to 0.21 in Model 2, confirming the positive influence on banks' cost efficiency of including non-earning assets among the outputs.

Moreover, confirming our previous results, excluding the banks from the five EU countries that received external financial assistance (Panel 6) reinforces the variance of the error that is due to the inefficiency term; conversely, excluding Italian banks (Panel 4) reduces the contribution of the variance of the inefficiency error terms to that of the total error term in the estimated bank cost efficiency function.

Summarizing our results, Table 6 presents the rankings of each panel in terms of the percent

Table 6. Rankings of the Panels Considered in this Analysis

\begin{tabular}{ccccc}
\hline Panel $^{(*)}$ & $\begin{array}{c}\text { Ranking according } \\
\text { to the \% of the total } \\
\text { banks in the sample }\end{array}$ & $\begin{array}{c}\text { Ranking according } \\
\text { to the \% of the } \\
\text { provided loans in 2017 }\end{array}$ & $\begin{array}{c}\text { Ranking according } \\
\text { to the values of the } \\
\text { gamma - Model 1 }\end{array}$ & $\begin{array}{c}\text { Ranking according } \\
\text { to the values of the } \\
\text { gamma - Model 2 }\end{array}$ \\
\hline Panel 1 & - & - & 3 & 2 \\
Panel 2 & 3 & 1 & 5 & 4 \\
Panel 3 & 2 & 4 & 4 & 3 \\
Panel 4 & 1 & 5 & 6 & 5 \\
Panel 5 & 4 & 2 & 2 & 5 \\
Panel 6 & 5 & 3 & 1 & 1 \\
\hline
\end{tabular}

Notes. ${ }^{(*)}$ Panel 1: Banks from all EU countries; Panel 2: Excluding France; Panel 3: Excluding Germany; Panel 4: Excluding Italy; Panel 5: Excluding the UK; Panel 6: Excluding five EU countries (i.e., Cyprus, Greece, Ireland, Portugal, and Spain). 
of the total banks in our sample; the percent of total loans provided in 2017; and the contribution of the inefficiency error term to the total variance, given by gamma $(\gamma)$, in both models.

Table 6 reveals that Italian banks, which are not included in Panel 4, are the most numerous in our sample. However, they rank fifth in terms of loans provided in 2017 and appear to be the least efficient in our sample.

Conversely, the most efficient banks are those that are excluded from Panel 6 (i.e., the banks from the five EU countries that received external financial assistance), although they rank fifth in terms of the number of banks in our sample and third in terms of loans provided in 2017.

French banks, which are excluded from Panel 2, rank third in terms of the number of banks but provided the most loans in 2017. In terms of efficiency, their performance is not remarkable, particularly in Model 1, which includes three outputs. In both models, the performance of French banks is lower than that of the full sample of banks considered in our estimations (i.e., those included in Panel 1). We find similar results for German banks, which are excluded from Panel 3 , as they appear to be less efficient than the full sample of banks, particularly in Model 1. Moreover, German banks are very prominent in our sample, as they rank second in terms of the number of banks, but they are not particularly important in terms of loans provided in 2017.

Finally, UK banks, which are excluded from Panel 5, are not very numerous, ranking fourth in terms of the number of banks, but they rank second in terms of loans provided. In terms of efficiency, they rank much higher in Model 1. Thus, unlike French and German banks, UK banks can be more efficient relative to the full set of EU banks included in our sample, but only when we consider the model with three outputs. However, in Model 2, which includes only two outputs, UK banks appear less efficient than almost all of the other EU banks in our sample.

\section{Concluding Remarks}

This study applies SFA techniques to data from the BankFocus database from Moody's Analytics for the period 2011-2017. We follow the intermediation approach and use the available data to estimate a cost function with total costs (more precisely, the sum of interest and non-interest expenses) as the dependent variable.

We consider two models: one with three outputs (i.e., total loans, other earning assets, and non-earning assets) and one with only two outputs (i.e., excluding non-earning assets). Both models consider two inputs (i.e., the price of borrowed funds and the price of physical capital and labor). Our estimations also include four control variables: the ratio of bank equity to 
total assets, the ratio of off-balance sheet items to total assets, the ratio of non-performing loans to gross loans, and the ratio of profits before tax to average assets.

We contribute to the existing literature on bank efficiency by specifically focusing on the EU banking sector and answering the two research questions described in the introduction. Specifically, we investigate EU banks' efficiencies in the aftermath of the global financial crisis and estimate their performance in the Brexit scenario and hypothetical scenarios in which banks from other specific countries exit the EU.

The results of this analysis provide clear evidence of bank cost inefficiencies during the period 2011-2017. We observe inefficiencies in the full sample of 485 banks from all current 28 EU member-states (included in Panel 1) and in all of the considered subsamples (Panels 2-6). In all panels, inefficiency is higher when we include only two outputs in our estimations.

We also consider hypothetical scenarios that include Brexit; the exits of France, Germany, and Italy, which are three other financially relevant EU countries; and the exit of five countries that were deeply affected by the global financial and sovereign crisis (i.e., Cyprus, Greece, Ireland, Portugal, and Spain). The results indicate that bank inefficiency would increase if the banks of the latter five countries exited the EU. In contrast, the exit of the Italian banks would clearly improve bank efficiency. Thus, in our sample, the Italian banks are the least efficient, and the banks from the five countries that were most affected by the global financial crisis and requested international financial assistance are the most efficient.

The relevance of French and German banks is not entirely balanced in our sample. German banks are numerous but are not particularly relevant in terms of loans provided; conversely, French banks are less numerous than German banks but are particularly relevant in terms of loans provided. In terms of efficiency, however, both French and German banks perform worse relative to the full sample of EU banks considered in our estimations.

The UK banks included in our sample are not particularly numerous but are rather relevant in terms of loans provided. The cost efficiency results for these banks differ across the two considered models. In Model 2, which includes only two outputs, the UK banks in our sample perform worse than the French and German ones do. However, if we include three outputs (i.e., total loans, other earning assets, and non-earning assets), UK banks are more efficient relative to the full sample of EU banks.

In summary, despite the evident cost inefficiencies of the EU banks included in our sample, we observe significant differences across countries. Brexit, and the eventual exits of other relevant countries, will surely have consequences in terms of bank efficiency. At least in our sample, however, the exits of the French, German, and, particularly, the Italian banks may improve overall bank efficiency. Conversely, based on the results obtained with this sample of banks, the overall cost efficiency of EU banks would decrease following the exit of the five EU member-states that were most affected by the global financial crisis, requested 
international financial assistance, and were obligated to restructure their banking sectors.

From these results, we can conclude that, in terms of bank cost efficiency, particular attention should be paid not only to UK banks but also to French and German banks and particularly to Italian banks.

However, the results do not allow us to conclude that financial assistance would solve the problems of all EU banks, nor do they provide specific recommendations in terms of the identified inefficiencies. Further research in this field is still needed. Future studies should consider other variables as bank outputs or inputs, use different kinds of efficiency estimates, and evaluate other samples of EU and non-EU banks.

We should also note that Brexit, as well as the eventual exits of other countries from the $\mathrm{EU}$, is expected to produce deep structural changes that are not analyzed in this study but that deserve specific attention, justifying additional research in this field. Moreover, EU banks' performance should be analyzed by taking into account the long process of financial integration and the recent creation of the Banking Union.

\section{References}

Aiello, F., \& Bonanno, G. (2013). Profit and cost efficiency in the Italian banking industry (2006-2011). Economics and Business Letters, 2(4), 190-205.

Aiello, F., \& Bonanno, G. (2015). Efficiency in banking: a meta-regression analysis. International Review of Applied Economics, 30(1), 112-149.

Aigner, D. J., Lovell, C. A. K., \& Schmidt, P. (1977). Formulation and estimation of stochastic frontier production function models. Journal of Econometrics, 6(1), 21-37.

Albertazzi, U., \& Gambacorta, L. (2009). Bank profitability and the business cycle. Journal of Financial Stability, 5(4), 393-409.

Ali, A. I., \& Seiford, L. M. (1993). The mathematical programming approach to efficiency Analysis. In H. O. Fried, C. A. K. Lovell, \& S. S. Schmidt (Eds.), The Measurement of Productive Efficiency (pp. 120-159). New York: Oxford University Press.

Altunbas, Y., Gardener, E. P. M., Molyneux, P., \& Moore, B. (2001). Efficiency in European banking. European Economic Review, 45(10), 1931-1955.

Apergis, N. (2015). Competition in the banking sector: New evidence from a panel of emerging market economies and the financial crisis. Emerging Markets Review, 25(C), 154-162.

Apergis, N., \& Alevizopoulou, E. (2011). Bank efficiency: Evidence from a panel of European banks. Panoeconomicus, 3, 329-341.

Athanasoglou, P., Brissimis, S. N., \& Delis, M. D. (2008). Bank-specific, industry-specific and macroeconomic determinants of bank profitability. Journal of International Financial Markets, Institutions and Money, $18(2), 121-136$. 
Barros, C., Ferreira, C., \& Williams, J. (2007). Analysing the determinants of performance of best and worse European banks: A mixed logit approach. Journal of Banking and Finance, 31(7), 2189-2203.

Battese, G. E., \& Coelli, T. (1988). Prediction of firm-level technical efficiencies with a generalized frontier production function and panel data. Journal of Econometrics, 38(3), 387-399.

Battese, G. E., \& Coelli, T. (1995). A model for technical inefficiency effects in a stochastic frontier production function for panel data. Empirical Economics, 20(2), 325-332.

Belke, A., Haskamp, U., \& Setzer, R. (2016). Regional bank efficiency and its effect on regional growth in "normal" and "bad" times. Economic Modelling, 58, 413-426.

Berger, A. N., \& Humphrey, D. B. (1991). The dominance of inefficiencies over scale and product mix economies in banking. Journal of Monetary Economics, 28(1), 117-148.

Berger, A. N., \& Mester, L. J. (1997). Inside the black box: What explains differences in inefficiencies of financial institutions? Journal of Banking and Finance, 21(7), 895-947.

Bikker, J. A. (2003). Efficiency and cost differences across countries in a unified European banking market (DNB Staff Reports (discontinued) 87). Netherlands Central Bank.

Bikker, J. A., Shaffer, S., \& Spierdijk, L. (2012). Assessing competition with the Panzar-Rosse model: The role of scale, costs, and equilibrium. Review of Economics and Statistics, 94(4), 1025-1044.

Bos, J. W. B., \& Kool, C. J. M. (2006). Bank efficiency: The role of bank strategy and local market conditions. Journal of Banking and Finance, 30(7), 1953-1974.

Bos, J. W. B., \& Schmiedel, H. (2007). Is there a single frontier in a single European banking market? Journal of Banking and Finance, 31(7), 2081-2102.

Boussemart, J-Ph., Leleu, H., Shen, Z., Vardanyan, M., \& Zhu, N. (2017). Decomposing banking performance into economic and risk management efficiencies. Working Papers 2017-EQM-09, IESEG School of Management.

Casu, B., Girardone, C., \& Molyneux, P. (2004). Productivity change in European banking: A comparison of parametric and non-parametric approaches. Journal of Banking and Finance, 28(10), 2521-2540.

Charnes A., Cooper W. W., \& Rhodes, E. (1978). Measuring the efficiency of decision-making units. European Journal of Operational Research, 2(6), 429-444.

Charnes, A., Cooper W. W., Lewin, A. Y., \& Seiford, L. M. (1994). Data envelopment analysis: Theory, methodology and application. Boston: Kluwer Academic Publishers.

Chen, T. Y, Chen, C. B., \& Peng, S. Y. (2008). Firm operation performance analysis using data envelopment analysis and balanced scorecard: A case study of a credit cooperative bank. International Journal of Productivity and Performance Management, 57(7), 523-539.

Chiu, Y. H., Chen, Y. C., \& Bai, X. J. (2011). Efficiency and risk in Taiwan banking: SBM super-DEA estimation. Applied Economics, 43(5), 587-602.

Colesnic, O., Kounetas, K., \& Polemis, M. (2018). Estimating risk efficiency in MiddleEast banks before and after the crisis. A Metafrontier framework (MPRA Paper 84795). University Library of Munich, Germany.

Cook, W. D., Tone, K., \& Zhu, J. (2014). Data envelopment analysis: Prior to choosing a model. Omega, $44,1-4$.

Cooper, W. W., Seiford, L. M., \& Tone, K. (2006). Data envelopment analysis: A comprehensive text 
with models, applications, references and DEA-solver software, 2nd Ed. New York: Springer.

Delis, M. D., Koutsomanoli-Fillipaki, A., Staikouras, C. K., \& Gerogiannaki, K. (2009). Evaluating cost and profit efficiency: A comparison of parametric and non-parametric methodologies. Applied Financial Economics, 19(3), 191-202.

Doan, A.-T., Lin, K.-L., \& Doong, S.-C. (2018). What drives bank efficiency? The interaction of bank income diversification and ownership. International Review of Economics \& Finance, 55, 203-219.

Farrell, M. J. (1957). The measurement of productive efficiency. Journal of the Royal Statistical Society, $120(3), 253-290$.

Federico, B., Daidone, S., Ilardi, G., \& Atella, V. (2013). Stochastic frontier analysis using Stata. Stata Journal, 13(4), 718-758.

Ferreira, C. (2020). Evaluating the European bank efficiency using Data Envelopment Analysis: Evidence in the aftermath of the recent financial crisis. International Advances in Economic Research, 26(4), 391-405.

Goddard, J., Molyneux, P., \& Williams, J. (2014). Dealing with cross-firm heterogeneity in bank efficiency estimates: Some evidence from Latin America. Journal of Banking and Finance, 40, 130-142.

Greene, W. M. (1990). A gamma-distributed stochastic frontier model. Journal of Econometrics, 46(1-2), 141-163.

Greene, W. M. (2005). Reconsidering heterogeneity in panel data estimators of the stochastic frontier model. Journal of Econometrics, 126(2), 269-303.

Guarda, P., Rouabah, A., \& Vardanyan, M. (2013). Identifying bank outputs and inputs with a directional technology distance function. Journal of Productivity Analysis, 40, 185-195.

Hughes, J. P., \& Moon, C. G. (2018). How bad is a bad loan? Distinguishing inherent credit risk from inefficient lending (Does the capital market price this difference?). Department of Economics, Rutgers University, Working Paper No. 201802.

Jondrow, J., Lovell, C. A. K., Materov, I. S., \& Schmidt, P. (1982). On the estimation of technical inefficiency in the stochastic frontier production function model. Journal of Econometrics, 19(2-3), 233-238.

Kocisova, K. (2017). Measurement of revenue efficiency in European Union countries: A comparison of different approaches. International Journal of Applied Business and Economic Research, 15(9), $31-42$.

Koetter, M., \& Poghosyan, T. (2009). The identification of technology regimes in banking: Implications for the market power-fragility nexus. Journal of Banking and Finance, 33(8), 1413-1422.

Kok, C., Móré, C., \& Pancaro, C. (2015). Bank profitability challenges in euro area banks: The role of cyclical and structural factors. ECB Financial Stability Review, 1, 134-145.

Kuc, M. (2018). Cost efficiency of European cooperative banks. Institute of Economic Studies (IES) Working paper 21/2018.

Lovell, C. A. K. (1993). The mathematical programming approach to efficiency analysis. In H. O. Fried, C. A. K. Lovell, \& S. S. Schmidt (Eds.), The Measurement of Productive Efficiency (pp. 3-67). New York: Oxford University Press.

Lozano-Vivas, A., \& Pasiouras, F. (2010). The impact of non-traditional activities on the estimation of bank efficiency: international evidence. Journal of Banking and Finance, 34(7), 1051-1076. 
Lozano-Vivas, A., Kumbhakar, S. C., Fethi, M. D., \& Shaban, M. (2011). Consolidation in the European banking industry: How effective is it? Journal of Productivity Analysis, 36, 247-261.

Maggi, E. F. B. (2016). Bank financial word crisis: inefficiencies and responsibilities. DSS Empirical Economics and Econometrics Working Papers Series, DSS-E3 WP 2016/2.

Mamatzakis, E. (2015). Risk and efficiency in the Central and Eastern European banking industry under quantile analysis. Quantitative Finance, 15(3), 553-567.

Martinho, R., Oliveira, J., \& Oliveira, V. (2017). Bank profitability and macroeconomic factors. Banco de Portugal, Financial and Stability Papers, No. 5.

Matthews, K. (2010). Banking efficiency in emerging market economies. Cardiff Economics Working Papers E2010/12. Cardiff University, Cardiff Business School.

Oliveira, J. (2017). Inefficiency distribution of the European banking system. Banco de Portugal, Working Paper No. 12.

Resti, A. (1997). Evaluating the cost-efficiency of the Italian banking system: What can be learned from the joint application of parametric and non-parametric techniques. Journal of Banking and Finance, 21(2), 221-250.

Rossi, S., Schwaiger, M., \& Winkler, G. (2005). Managerial behaviour and cost/profit efficiency in the banking sectors of Central and Eastern European countries. Working Paper 96. Oesterreichische Nationalbank.

Sealey, C., \& Lindley, J. T. (1977). Inputs, outputs and a theory of production and cost at depository financial institution. Journal of Finance, 32(4), 1251-1266.

Tuskan, B., \& Stojanovic, A. (2016). Measurement of cost efficiency in the European banking industry. Croatian Operational Research Review, 7(1), 47-66.

Vozková, K., \& Kuc, M. (2017). Cost efficiency of European cooperative banks. International Journal of Economics and Management Engineering, 11(11), 2705-2708.

Weill, L. (2009). Convergence in banking efficiency across European countries. Journal of International Financial Markets, Institutions and Money, 19(5), 818-833.

Wooldridge, J. M. (2010). Econometric analysis of cross section and panel data. Cambridge, MA: MIT Press.

Yildirim, H. S., \& Philippatos, G. C. (2007). Efficiency of banks: Recent evidence from the transition economies of Europe, 1993-2000. The European Journal of Finance, 13(2), 123-143. 
Annex I. Number of Banks and Their Representativeness by EU Member-State

\begin{tabular}{|c|c|c|c|}
\hline EU country ${ }^{(*)}$ & Number of banks & $\%$ of the total banks & $\%$ of the provided loans in 2017 \\
\hline Austria & 20 & 4.12 & 1.97 \\
\hline Belgium & 7 & 1.44 & 2.93 \\
\hline Bulgaria & 5 & 1.03 & 0.07 \\
\hline Croatia & 7 & 1.44 & 0.09 \\
\hline Cyprus & 3 & 0.62 & 0.08 \\
\hline Czech Rep. & 8 & 1.65 & 0.47 \\
\hline Denmark & 31 & 6.39 & 2.94 \\
\hline Estonia & 2 & 0.41 & 0.02 \\
\hline Finland & 5 & 1.03 & 0.54 \\
\hline France & 43 & 8.87 & 22.69 \\
\hline Germany & 103 & 21.24 & 10.17 \\
\hline Greece & 6 & 1.24 & 0.76 \\
\hline Hungary & 7 & 1.44 & 0.17 \\
\hline Ireland & 4 & 0.82 & 0.78 \\
\hline Italy & 105 & 21.65 & 8.96 \\
\hline Latvia & 1 & 0.21 & 0.02 \\
\hline Lithuania & 4 & 0.82 & 0.06 \\
\hline Luxembourg & 9 & 1.86 & 0.44 \\
\hline Malta & 3 & 0.62 & 0.04 \\
\hline Netherlands & 16 & 3.30 & 9.43 \\
\hline Poland & 14 & 2.89 & 0.98 \\
\hline Portugal & 6 & 1.24 & 0.98 \\
\hline Romania & 4 & 0.82 & 0.11 \\
\hline Slovakia & 7 & 1.44 & 0.12 \\
\hline Slovenia & 6 & 1.24 & 0.07 \\
\hline Spain & 13 & 2.68 & 8.95 \\
\hline Sweden & 7 & 1.44 & 3.98 \\
\hline UK & 39 & 8.04 & 22.16 \\
\hline
\end{tabular}

Note. (*) The data used in this study are taken from the BankFocus database from Moody's Analytics. 


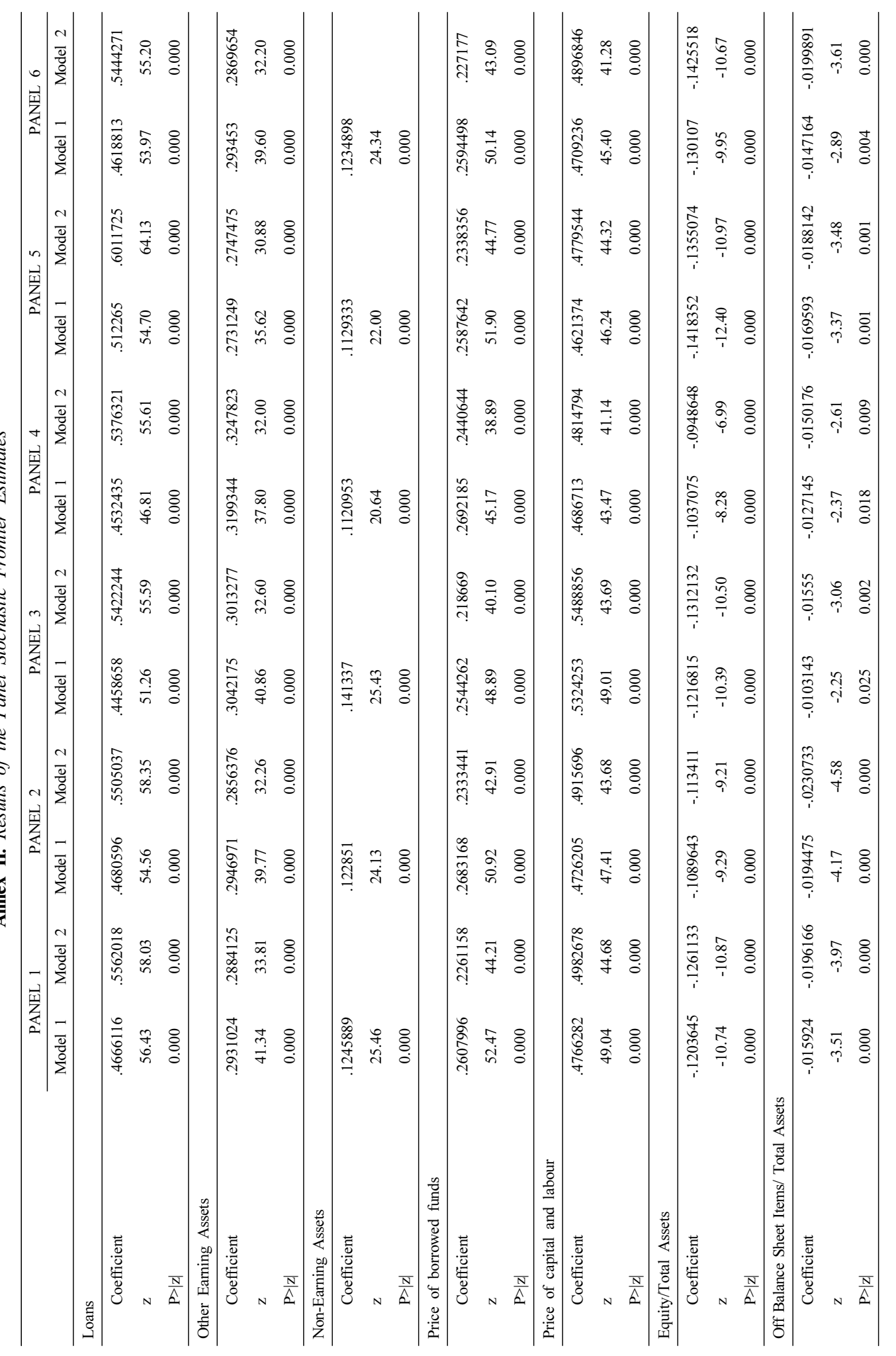


124 Journal of Economic Integration Vol. 36, No. 1

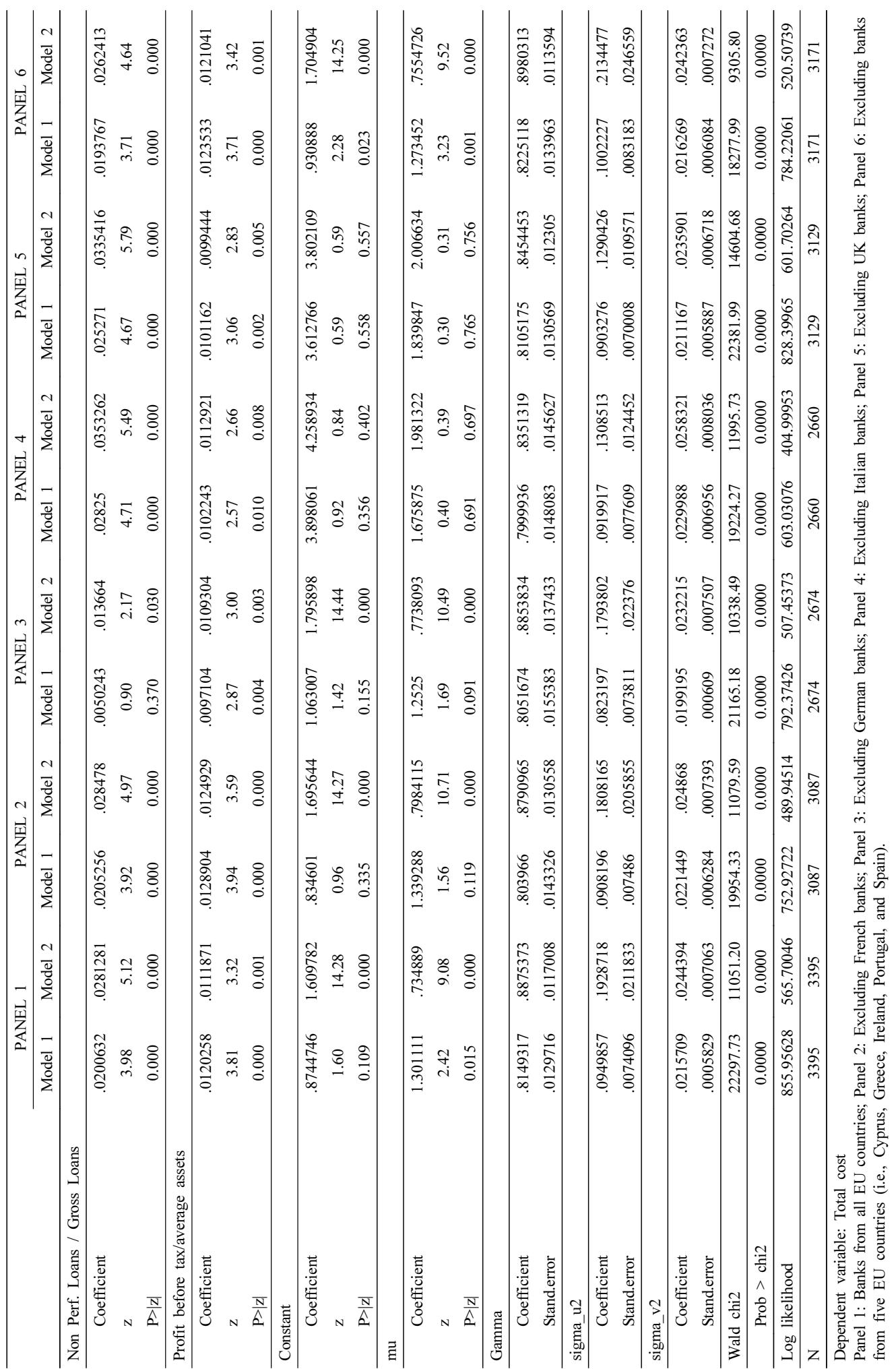

